\title{
Glacier shrinkage in the Ebinur lake basin, Tien Shan, China, during the past 40 years
}

\author{
Lin WANG, ${ }^{1}$ Zhongqin $\mathrm{LI}^{1}{ }^{1}$ Feiteng WANG, ${ }^{1,2}$ Ross EDWARDS ${ }^{2}$ \\ ${ }^{1}$ State Key Laboratory of Cryospheric Sciences/Tien Shan Glaciological Station, Cold and Arid Regions Environment and \\ Engineering Research Institute, Chinese Academy of Sciences, Lanzhou, China \\ E-mail: tingting729@163.com \\ ${ }^{2}$ Department of Imaging and Applied Physics, Curtin University, Perth, Western Australia, Australia
}

\begin{abstract}
The Ebinur lake basin, Tien Shan, China, was described in the early 20th century as the 'Green Labyrinth'. This relatively productive area supports agriculture and stands in contrast to the regional aridity. Glacier melt runoff is an important source of water for this arid region and has played a significant role in its economic development. However, over the past 40 years the ecology and environment of the region have seriously degenerated due to human activity and climate change. To investigate changes in glacier water supply, measurements from two reference glaciers were performed and used to validate satellite data and historical data for glaciers in the water catchment. Variability in regional glacier total area and volume over the past 40 years was reconstructed from historical documents, aerial photographs and remote-sensing data. Our investigations of $\mathbf{4 4 6}$ glaciers showed that from 1964 to 2004 the total glacier area decreased by $14.7 \%\left(0.4 \% \mathrm{a}^{-1}\right)$, corresponding to an estimated volume change of $\mathbf{2 0 . 5 \%}$. During this period, the most dramatic decrease in glacier area corresponded to a rapid rise in temperature. This reduction in glacier area is accelerating and impacting the future sustainability of the region's water resources.
\end{abstract}

KEYWORDS: glacier fluctuations

\section{INTRODUCTION}

The cryosphere on land stores $\sim 75 \%$ of the world's fresh water (Lemke and others, 2007). Changes in glacier extent in mountainous regions are widely recognized as one of the best natural indicators of global climate change (Haeberli, 2005; Oerlemans, 2005). During the past 50 years, the average air temperature in northwest China has increased by 1.6-1.8 ${ }^{\circ} \mathrm{C}$ ( $\mathrm{Li}$ and others, 2013). The Intergovernmental Panel on Climate Change (IPCC) has projected that if greenhouse gas emissions, the leading cause of climate change, continue to rise, then mean global temperatures will increase by $1.4-5.8^{\circ} \mathrm{C}$ by the end of the 21 st century (Lemke and others, 2007). With the ongoing climate warming, alpine glacier retreat has accelerated (Paul and others, 2002, 2004a; Khromova and others, 2003; Bolch and others, 2009). As in many other parts of the world, glaciers in the Tien Shan, China, have been retreating since the end of the Little Ice Age of the mid-19th century, a tendency that has accelerated since the 1970s (Solomina and others, 2004; Narama and others, 2010; Sorg and others, 2012). Intensified glacier melt has caused the glaciers to have a mainly negative mass balance and strongly affects the quantity and seasonal distribution of runoff in central Asia's glacier-fed watersheds (Aizen and others, 1997; Hagg and others, 2007; Sorg and others, 2012). Correct evaluation of glacier area and volume change has wide practical applications in water resource, water supply and hydropower assessments (Aizen and others, 2006).

In arid and semi-arid regions, especially in northwest China, glacier runoff is the main contributor to water resources that are used to support the sustainable development of the environment, industry and agriculture (Yao and others, 2004). Ebinur lake is the largest saltwater lake, and the second largest lake, in Xinjiang (Ma and others, 2007).
Hence, glacier change in the Ebinur lake basin attracts wide attention, and glacier monitoring and investigation is important as climate change continues to affect the basin. The aim of this study is to evaluate glacier fluctuations in a regional context in the Ebinur lake basin from 1964 to 2004, analyzing the causes of glacier changes in the basin and studying the essential relationships between climate, glaciers and runoff.

\section{STUDY AREA}

The Ebinur lake basin $\left(43^{\circ} 38^{\prime}-45^{\circ} 52^{\prime} \mathrm{N}, 79^{\circ} 53^{\prime}-85^{\circ} 02^{\prime} \mathrm{E}\right)$ is located on the north slope of the western Tien Shan and southwest of the Junggar basin, China (Fig. 1). The total area of the basin is $50621 \mathrm{~km}^{2}$ ( $\mathrm{Li}$ and others, 2006). It is surrounded by mountains to the north, west and south (mountainous area $24317 \mathrm{~km}^{2}$ ). There is a typical temperate arid continental climate, with the mountain-oasis-desert system having the typical characteristics of temperate arid ecology. The glacier melt runoff of this region has played a significant role in the economic development of Xinjiang Autonomous Region.

The China Glacier Inventory (Liu and Ding, 1986) identified 1104 glaciers contributing to the water source of the Ebinur lake basin in the 1960s (Table 1). These glaciers had a total estimated area of $823.1 \mathrm{~km}^{2}$, an ice volume of $47 \mathrm{~km}^{3}$ and a mean glacier area of $0.75 \mathrm{~km}^{2}$. Ebinur lake is a terminal lake fed by the Kuitun, Sikeshu, Jinghe and Daheyanzi rivers, as well as Sailimu lake and the Bortala river. Because of the distribution and number of glaciers supplying each river, this study does not include the Daheyanzi river and Sailimu lake. The 40 year study period (1964-2004) saw large-scale land reclamation and population growth around the Ebinur lake basin, and by the end of 

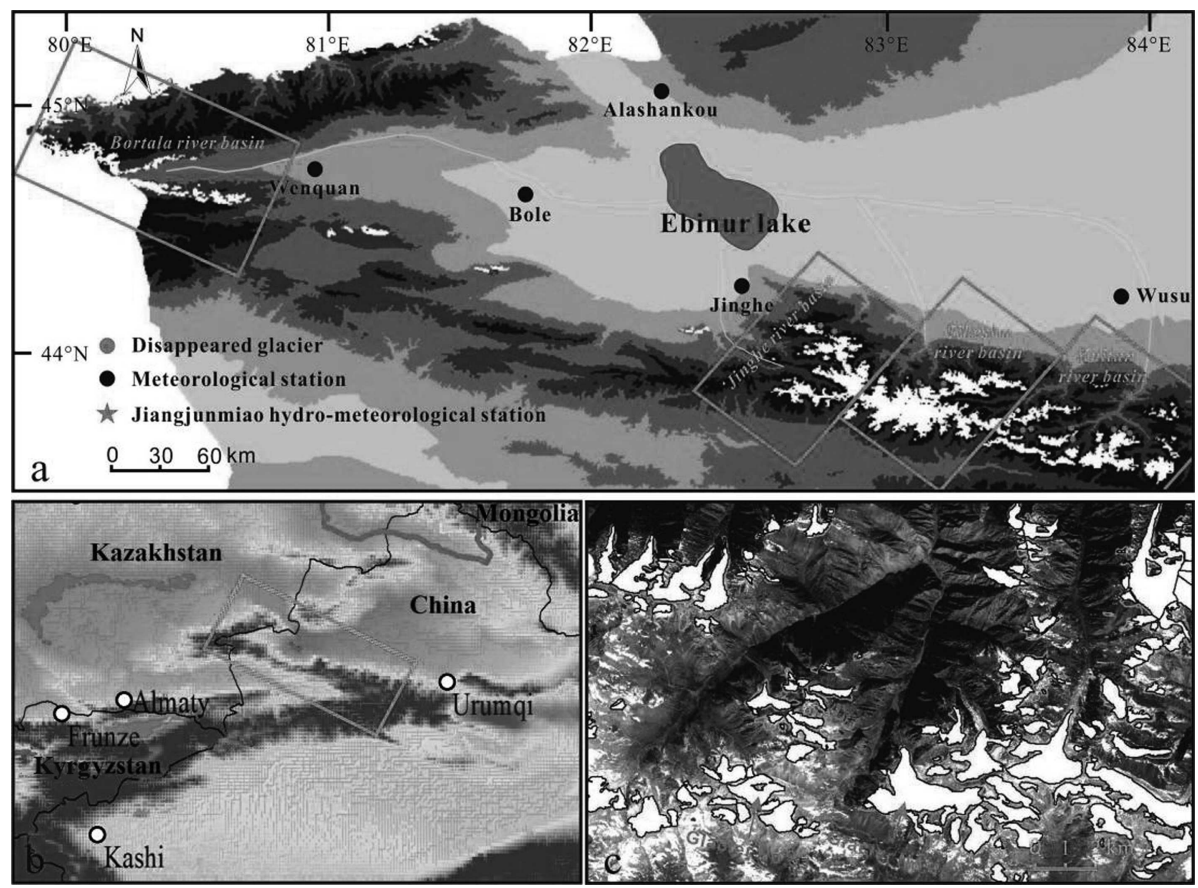

Fig. 1. Location of the Ebinur lake basin, Tien Shan: (a) study region; (b) location of Ebinur lake basin in Xinjiang region; (c) glaciers No. 48 and No. 51 and the glacier outlines in 2004 (black) and 1964 (blue) in the Kuitun river basin.

the study period only the Jinghe and Bortala rivers still flowed into the basin. Glacier position monitoring (glaciers No. 48 and No. 51; Fig. 1c) in the Ebinur lake basin (Kuitun river basin) from 1999 to 2010 has enhanced glacier mapping and studies of ablation, debris cover and glacier distribution in the region. The fieldwork is maintained by the Tien Shan Glaciological Station; the observations include glacier mass balance, terminal position, debris, surface velocity, discharge and meteorological data (Xiao and others, 2012).

\section{DATA AND METHODS}

\subsection{Satellite data and processing}

To determine relative changes in glacier area over the past 40 years, two periods were selected based on the availability of reliable historical data and field-based validation of satellite imagery in the modern era. The modern data include one SPOT-5 (Satellite Pour l'Observation de la Terre5) image and three ASTER (Advanced Spaceborne Thermal

Table 1. Summary of glacier distributions in the upper reaches of the Ebinur lake basin

\begin{tabular}{lcccc}
\hline \multirow{2}{*}{ Basin } & \multicolumn{3}{c}{ China Glacier Inventory III } & \multicolumn{2}{c}{ This study } \\
& Number & Area & Number & Area \\
& & $\mathrm{km}^{2}$ & & $\mathrm{~km}^{2}$ \\
& & & & \\
\hline Kuitun river basin & 309 & 201 & 133 & 87.1 \\
Sikeshu river & 364 & 336 & 150 & 114 \\
Jinghe river & 129 & 96 & 91 & 91.4 \\
Daheyanzi river & 34 & 4.17 & & \\
Sailimu lake & 13 & 4.28 & & \\
Bortala river & 255 & 181 & 72 & 73.31 \\
Total & $\mathbf{1 1 0 4}$ & $\mathbf{8 2 3}$ & $\mathbf{4 4 6}$ & $\mathbf{3 6 6}$ \\
\end{tabular}

Emission and Reflection Radiometer) images from June to September 2004 and 2005, with a resolution of 5-15 m. Field-based measurements of two glaciers (glaciers No. 48 and No. 51), covered by the satellite imagery, were conducted from 1999 to 2005. Historical datasets include 18 topographic maps ( $1: 50000)$, dating from 1962 to 1966 and derived from aerial photographs taken by the Chinese Military Geodetic Service. Satellite images were taken in (nearly) cloud-free conditions during periods of minimal snow cover in order to reduce potential uncertainty in glacier boundary delineation.

A digital elevation model (DEM) of the Kuitun river basin at the 1:50000 scale (DEM5) was created by contour digitization and interpolation from the $1: 50000$ topographic maps. The DEM of the other three subregions had a resolution of $25 \mathrm{~m}$. The satellite images were orthorectified using methodologies described by Paul and others (2004b) and $\mathrm{PCl}$ Geomatica 9.1 Orthoengine software (Kutuzov and Shahgedanova, 2009; Svoboda and Paul, 2009). Geocorrection and co-registration were established using ERDAS Imagine 9.0 software. The clearly distinguishable terrain features were selected from topographic maps that could be identified on each image. On average, 30-50 ground control points were collected, with the root-mean-square error (RMSE) value limited to $<0.5$ pixels in both the $x$ and $y$ directions. All images and maps were presented in a Universal Transverse Mercator (UTM) coordinate system referenced to the 1984 World Geodetic System (WGS84).

\subsection{Glacier outline delineation}

The study of glacier variations depends mainly on the delineation of the glaciers from sequential, co-registered orthorectified images. Excellent images ensure clear glacier boundaries, minimizing uncertainty. The image was obtained for cloud-free conditions, making it immune to potential error, and at the end of the ablation period when snow cover was minimal, to avoid perturbation in 
delineating the glacier boundary. Data assessments conducted under the Global Land Ice Measurements from Space (GLIMS) framework confirmed that artificial interpretation remains the best tool for extracting higher-level information from satellite images for glaciers, especially debris-covered glaciers (Paul and others, 2004b; Raup and others, 2007a).

The glacier outlines are mapped manually with the DEM using commercial GIS software (ArcView), as well as using the topographic maps and satellite images. ArcView is a useful tool for extracting detailed information from satellite imagery of glaciers (Raup and others, 2007b), particularly when mapping is conducted by the same person using a combination of different types of imagery (Paul and others, 2002). A DEM with a grid spacing of $25 \mathrm{~m}$ was used to derive the elevation and slope orientation data for the glaciers. Area and other parameters of the glaciers in different periods can be computed from the extracted glacier polygons, resulting in a total sample of 446 glaciers. For some images and sections containing clouds or fresh snow cover, the outlines of some glaciers were not validated accurately; these were omitted. Some glaciers in the Ebinur lake basin are covered to a varying extent by supraglacial debris, which has the same spectral characteristics as the surrounding terrain and thus cannot be spectrally discerned from it. The debris outline was derived from ASTER data by on-screen digitizing and was verified by real-time kinematic GPS (RTK-GPS; Unistrong E650) surveys conducted in August 2004.

\subsection{Accuracy analysis}

Glacier area mapping from the comparatively low-resolution (15 m) ASTER image is less accurate than that from the SPOT-5 image $(5 \mathrm{~m})$, especially for the smaller (area $<0.1 \mathrm{~km}^{2}$ ) and debris-covered glaciers (Pan and others, 2013). The best imagery for studying changes in glacier area and volume is the higher-resolution satellite image (e.g. SPOT-5). However, obtaining good-quality images (no clouds and minimal seasonal snow cover) during similar time periods was difficult, so two different types of satellite imagery (SPOT-5 and ASTER) were used.

Fieldwork and interpretation methods are extremely important for ensuring accuracy (Paul and others, 2004b; L. Wang and others, 2011; P. Wang and others 2011). In the study of glacier remote sensing, error derives mainly from the uncertainty of glacier boundary extraction, sensor resolution and co-registration error. The first of these errors can only be reduced through field verification and glaciological experience. For the latter two types of error, the uncertainty of remote-sensing images can be evaluated using the formula to calculate their error (Ye and others, 2006). For multiple images, the linear uncertainty can be expressed as

$$
U_{\mathrm{L}}=\sqrt{\sum^{\lambda^{2}}}+\sqrt{\sum^{\delta^{2}}}
$$

where $U_{\mathrm{L}}$ is the measurement uncertainty of the glacier terminus, $\lambda$ is the original pixel resolution of each individual image or map, and $\delta$ is the registration error of each individual image compared to the topographic map.

Correspondingly, the area uncertainty between multiple images can be deduced and expressed as

$$
U_{\mathrm{A}}=\sum^{\lambda^{2}} \cdot \frac{2 U_{\mathrm{L}}}{\sqrt{\sum^{\lambda^{2}}}}+\sum^{\delta^{2}}
$$

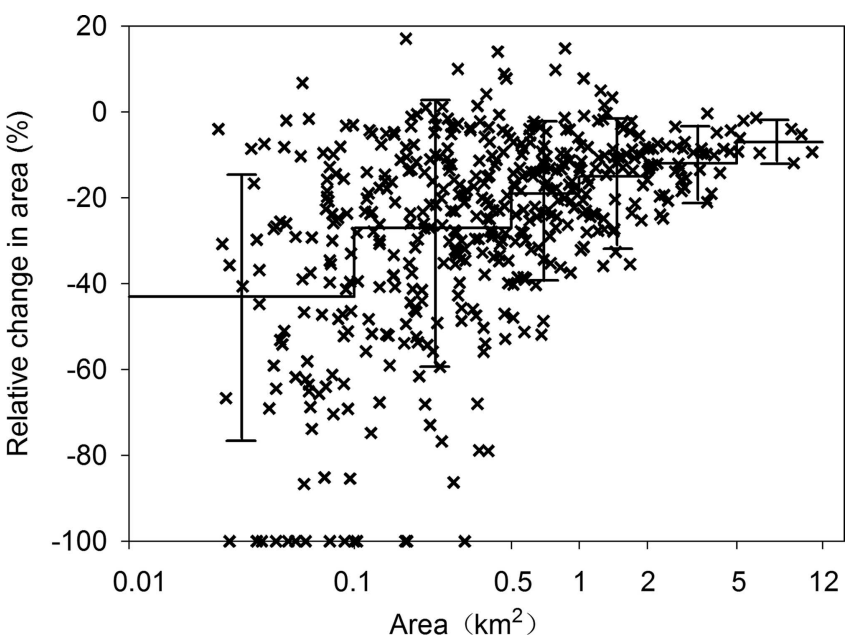

Fig. 2. Relationship between relative area change and initial glacier size for 446 glaciers in the Ebinur lake basin. Mean values of glacier area change (horizontal line) together with standard deviation (vertical bar) are given for the six area classes $(<0.1,0.1-0.5,0.5-1$, $1-2,2-5$ and $>5 \mathrm{~km}^{2}$ ).

where $U_{\mathrm{A}}$ is the measurement uncertainty of the glacier area and $U_{\mathrm{L}}$ is the linear uncertainty. In our case, glacier terminus and area measurement uncertainty can be calculated using Eqns (1) and (2), and the resulting values are $28.7 \mathrm{~m}$ and $0.001 \mathrm{~km}^{2}$, respectively. In this study, in order to verify and improve the accuracy of glacier outlines, glaciers No. 48 and No. 51 were surveyed in August 2004 using RTK-GPS (accuracy is micrometer level). The results show that there is about $0.8 \%$ difference in length and $0.5 \%$ difference in area between our 200 surveyed points and the glacier mapping generated from ASTER and SPOT data.

\section{RESULTS}

\subsection{Glacier change in the Ebinur lake basin}

Changes in glacier area extracted from repeat satellite data show that glacier behavior has varied considerably within the Ebinur lake basin since 1964 (Fig. 2). The results show that the total area of the 446 studied glaciers decreased from $366.32 \mathrm{~km}^{2}$ to $312.53 \mathrm{~km}^{2}$, a loss of $53.79 \pm 0.03 \mathrm{~km}^{2}$ $(14.7 \%)$, equivalent to $0.4 \% \mathrm{a}^{-1}$ of the 1964 value, over a period of 40 years. About $78 \%$ of these glaciers are $<1 \mathrm{~km}^{2}$ in area. The mean length change of all analyzed glaciers between 1964 and 2004 was $-198.5 \pm 1.6{\mathrm{~m}\left(5.0 \mathrm{~m} \mathrm{a}^{-1}\right) \text {, or }}$ $15.6 \%$.

Regions dominated by small glaciers are generally more sensitive to change because small glaciers have a short response time to climate variability (Bahr and others, 1998; Ye and others, 2001). Thus, there is a strong bias toward the large number of small glaciers that decreased in area. Twelve lower-elevation glaciers with areas of $<0.3 \mathrm{~km}^{2}$, which were present on the topographic maps, had disappeared completely by 2004. Eight of these had been smaller than $0.1 \mathrm{~km}^{2}$. Eight of the twelve glaciers that disappeared were located in the Kuitun river basin; the others were in the Sikeshu and Jinghe river basins (Fig. 1a). The latter two subregions belong to the most easterly part of the Ebinur lake basin. Clear variations are seen in glacier shrinkage, which has been strongly affected by variations in climate due to the long distance from east to west of the 


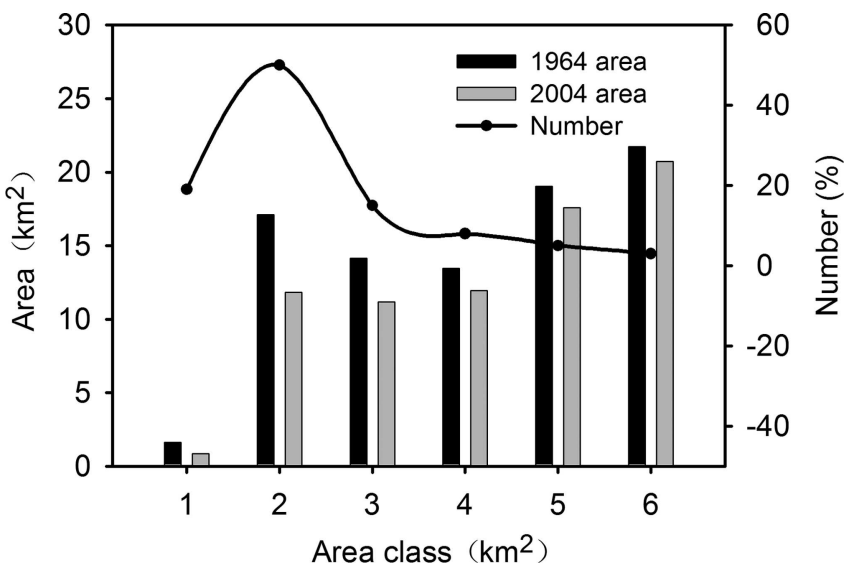

Fig. 3. Area, number, and area loss of glaciers by glacier size class for 1964-2004 in the Kuitun river basin (glacier size classes $1-6:<0.1,0.1-0.5,0.5-1,1-2,2-5$ and $>5 \mathrm{~km}^{2}$ respectively).

Ebinur lake basin. Meanwhile, 13 glaciers enlarged their areas, with an average rate of increase of $<7 \%$; most were smaller than $1.0 \mathrm{~km}^{2}$ and located on the lee side of the ridges. Accumulation on such glaciers depends mainly on snowdrift, and their behavior is determined by local conditions rather than climatic variations (P. Wang and others, 2011). The overriding importance of local conditions for the behavior of small glaciers has been noted by Surzakov and others (2007) for glaciers within the Altai mountains. Larger glaciers typically extend to lower elevations than those reached by smaller glaciers ( $\mathrm{Li}$ and others, 2011a). However, when subjected to climate warming, differences in area loss depend less on glacier elevation and more on glacier area, because smaller glaciers have a faster climate response ( $\mathrm{Li}$ and others, 2011a). In the Ebinur lake basin, glaciers that initially extended over $>2.0 \mathrm{~km}^{2}$ experienced an area loss of $9 \%$, whereas glaciers initially smaller than $1.0 \mathrm{~km}^{2}$ lost $22 \%$ of their area.

\subsection{Glacier change in the subregions}

\subsubsection{The Kuitun river basin}

Our investigations of glaciers in the Kuitun river basin covered by SPOT5 imagery identified 133 glaciers, with a mean glacier area of $0.65 \mathrm{~km}^{2}$. This region has the largest mean area of the four study regions. Figure 3 presents the distribution of glacier coverage in the Kuitun river basin according to glacier size class $(<0.1,0.1-0.5,0.5-1,1-2$, $2-5$ and $>5 \mathrm{~km}^{2}$ ). About $84 \%$ of all glaciers in the basin in 1964 were $<1 \mathrm{~km}^{2}$ and contributed $\sim 37.7 \%$ of the total area, while $\sim 50 \%$ of the glaciers had an area of $0.1-0.5 \mathrm{~km}^{2}$, accounting for $19.6 \%$ of the total area. About $12.8 \%$ of the glaciers had an area of $1-5 \mathrm{~km}^{2}$, accounting for $37.3 \%$ of the total area. Only four glaciers in this sample were larger than $5 \mathrm{~km}^{2}$; they had a combined area of $20.74 \mathrm{~km}^{2}$ and accounted for $25 \%$ of the total area. Small glaciers are remarkably prevalent in this region.

Over the 40 year period 1964-2004 the total glacier area in the Kuitun river basin decreased by $15.4 \%$ of the 1964 value, from $87.06 \mathrm{~km}^{2}$ to $73.69 \mathrm{~km}^{2}\left(0.4 \% \mathrm{a}^{-1}\right)$. The total area of glaciers $<0.1 \mathrm{~km}^{2}$ in extent decreased by $0.76 \mathrm{~km}^{2}$ $(46.9 \%)$, while the total area of glaciers $>5 \mathrm{~km}^{2}$ decreased by $0.98 \mathrm{~km}^{2}(4.5 \%)$. The maximum area loss was in the $0.1-0.5 \mathrm{~km}^{2}$ size class, with a $33.5 \%$ decrease from $17.1 \mathrm{~km}^{2}$ to $11.4 \mathrm{~km}^{2}$. These observations suggest that larger glaciers are responsible for greater ice loss to local water

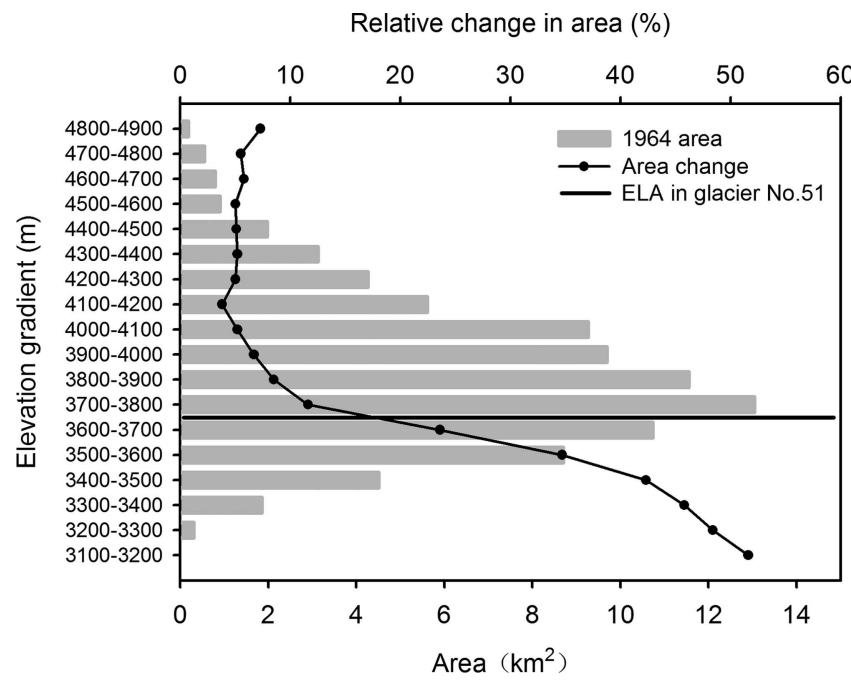

Fig. 4. Glacier area distribution vs elevation interval in the Kuitun river basin (black line shows the present ELA of glacier No. 51 reported from the field data).

resources than the more numerous small glaciers ( $\mathrm{Li}$ and others, 2011b). The mean area loss of individual glaciers that were $<0.1 \mathrm{~km}^{2}$ is $0.029 \mathrm{~km}^{2}$, compared to $0.245 \mathrm{~km}^{2}$ for glaciers $>5 \mathrm{~km}^{2}$ in area. Overall, glacial coverage decreased by $34.1 \%$ and $10.0 \%$ for the southern and northern slopes, respectively, indicating a significantly stronger area loss on the south-side glaciers of the Kuitun river basin.

Glaciers No. 51 and No. 48, located in the Kuitun river basin, have a history of glacial field monitoring (glacier No. 51 has the longer observation period, 1999-2012; the glacier No. 48 observation period was 2002-08). The field observations include surveys of the glacier boundary and terminus location by RTK-GPS and measurements of the mass balance by ablation stakes and snow pits. The ablation measurements are made using stakes inserted vertically into the glacier. According to field data, the law of multi-year average mass balance is better on glacier No. 51; ablation decreases with increasing altitude, with a maximum mass balance of $868.4 \mathrm{~mm}$ w.e. and a minimum value of $-2691 \mathrm{~mm}$ w.e. The glacier No. 51 field data show an area reduction of $13.0 \%$, from $1.558 \mathrm{~km}^{2}$ to $1.345 \mathrm{~km}^{2}$, an average reduction of $0.3 \% \mathrm{a}^{-1}$. The SPOT 5 imagery shows a similar relative change in area to that of the field study $\left(0.3 \% \mathrm{a}^{-1}\right)$. The modern average rate of loss was determined from 2000-06 field data using RTK-GPS. This rate was $0.9 \% \mathrm{a}^{-1}$, three times higher than the annual rate $\left(0.3 \% \mathrm{a}^{-1}\right)$ found by comparing modern and historical data (1964 and 2004). A DEM of the the Kuitun river basin at the $1: 50000$ scale (DEM5) was created by contour digitization and interpolation from the 1:50000 topographic maps (1964). The hypsography of glacier total area distribution by elevation intervals of $100 \mathrm{~m}$ is shown for 18 gradients, as derived from glacier polygons and the DEM, in Figure 4. The trend of glacier area with altitude increase is increasemaximum-decrease, with the maximum value at 3700$3800 \mathrm{~m}$ a.s.l. Nine of the gradients are at 3400-4300 m a.s.l., with a combined area of $77.36 \mathrm{~km}^{2}$ (88.9\% of the total area). The other nine have a combined area of $9.7 \mathrm{~km}^{2}(11.1 \%)$. The area-elevation relationship reflects the local topography and thermal lapse rate. Thus, glaciers usually develop in an elevation interval from the mountainside to the ridge ( $\mathrm{Li}$ and others, 2011a). In Figure 4, the horizontal line indicates the 

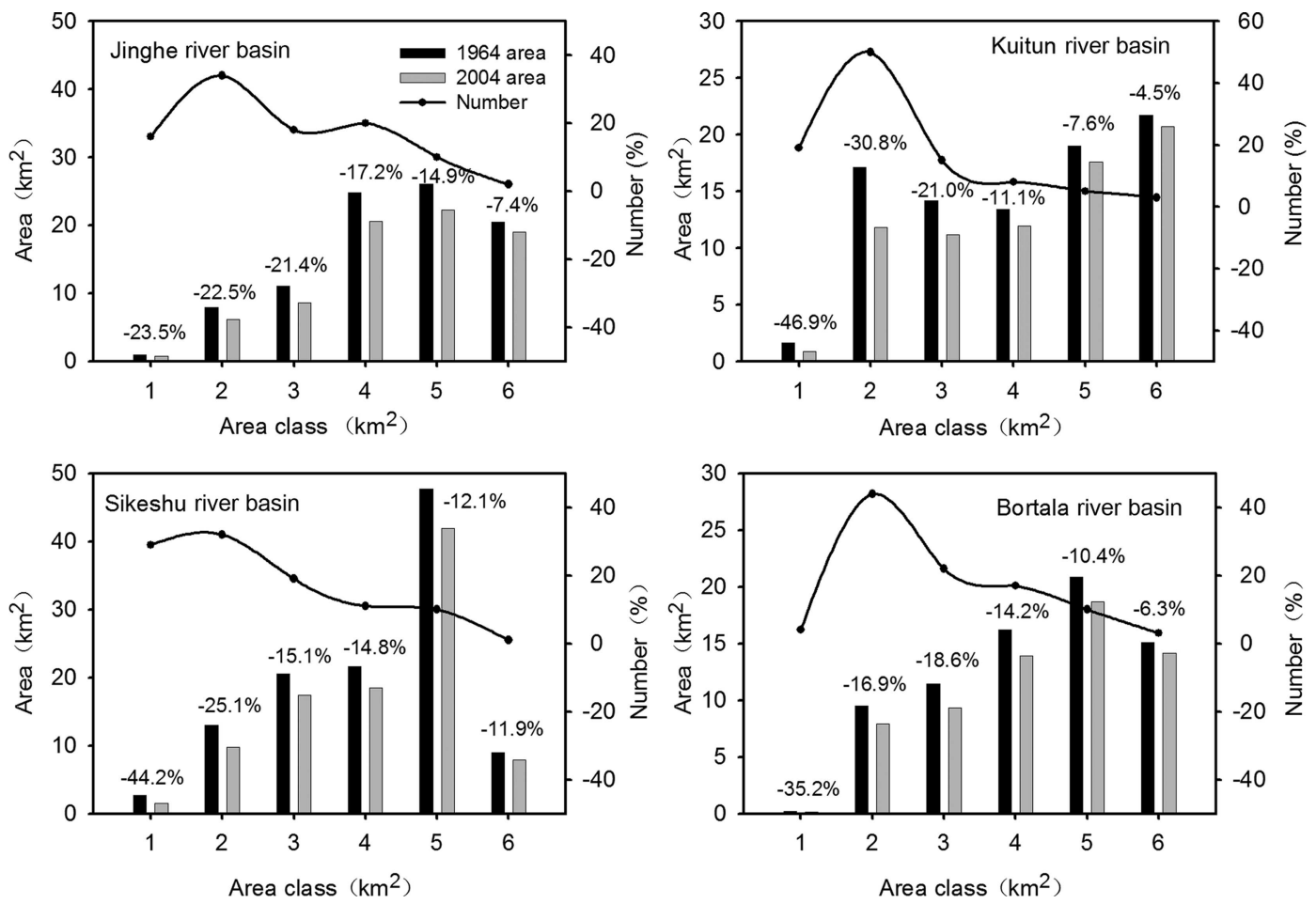

Fig. 5. Area, number, and area loss of glaciers by glacier size class for 1964-2004 in the four study subregions of the Ebinur lake basin (glacier size classes $1-6$ : $<0.1,0.1-0.5,0.5-1,1-2,2-5$ and $>5 \mathrm{~km}^{2}$ respectively).

present equilibrium-line altitude (ELA) $(3680 \mathrm{~m})$ of glacier No. 51, reported from the field data, which is similar to the peak of the glacier area distribution vs elevation interval. Thus, the glacier area distribution vs elevation interval probably reflects the ELA in regions that lack field data or are difficult to access (Narama and others, 2010). However, we acknowledge that topography may also be a factor.

There is a reduction in the glacier area from 3100 to $4900 \mathrm{~m}$ elevation. The largest glacier area $(51.6 \%)$ occurs at $3100-3200 \mathrm{~m}$, and the size of the reduction gradually decreases with increasing altitude (Fig. 4). Ablation occurs mainly below $4200 \mathrm{~m}$ (11 gradients at this elevation interval), with a combined area reduction of $12.29 \mathrm{~km}^{2}(91.9 \%$ of the total). The other seven gradients, above $4200 \mathrm{~m}$ a.s.l., have a total area reduction of only $1.08 \mathrm{~km}^{2}$ (extraction error is greater than for the entire study area at $\left.0.001 \mathrm{~km}^{2}\right)(8.1 \%)$. These results are consistent with those from the Qomolangma (Everest) protected area, indicating that the warming forced the glacier ablation area increase and the upslope movement of snowlines (Kehrwald and others, 2008).

\subsubsection{Other subregions and regional differences}

The other subregions are the Sikeshu, Jinghe and Bortala river basins. Glaciers in these three subregions are investigated using advanced spaceborne ASTER imagery. In the Sikeshu river basin, 150 glaciers were identified, with a mean area of $0.76 \mathrm{~km}^{2}$. Their total area decreased by $15.3 \%$, from $114.57 \mathrm{~km}^{2}$ to $96.98 \mathrm{~km}^{2}$, over the 40 year period 1964-2004 $\left(0.38 \% \mathrm{a}^{-1}\right)$, whereas over the 27 year period $1962-89$ it decreased by $2.6 \%\left(0.1 \% \mathrm{a}^{-1}\right)$ (Liu and others, 2002). The decrease has been intensified by the ablation trend in recent years. The Jinghe river basin contained 91 glaciers, with a mean area of $1.0 \mathrm{~km}^{2}$. Their total area decreased by $15.2 \%$, from $91.39 \mathrm{~km}^{2}$ to $77.42 \mathrm{~km}^{2}$, over the 40 year period $\left(0.38 \% \mathrm{a}^{-1}\right)$. The Bortala river basin contained 72 glaciers, with a mean area of $1.0 \mathrm{~km}^{2}$. Their total area decreased by $12.6 \%$, from $73.31 \mathrm{~km}^{2}$ to $64.07 \mathrm{~km}^{2}$, over the 40 year period $\left(0.32 \% \mathrm{a}^{-1}\right)$. Because the Bortala river basin is in the interior part of the Tien Shan, affected by local climatic conditions and glacier topography, it has a lower rate of glacier change than the other three subregions (Narama and others, 2010).

Figure 5 presents the distribution of glacier coverage in the four subregions from 1964 to 2004, according to glacier size class $(<0.1,0.1-0.5,0.5-1,1-2,2-5$ and $>5 \mathrm{~km}^{2}$ ). The distribution is similar in all the subregions. Glaciers with areas of $<1 \mathrm{~km}^{2}$ occupy $80 \%$ of the Sikeshu river basin, $68.1 \%$ of the Jinghe river basin and $70.8 \%$ of the Bortala river basin. The proportion of glaciers with areas of $0.1-0.5 \mathrm{~km}^{2}$ in these basins is $32 \%, 34 \%$ and $44 \%$, respectively. Small glaciers predominate, but larger glaciers were responsible for a greater ice loss to local water resources than the numerous small glaciers.

Thus, the relative abundance of glaciers in the different size classes strongly affects the total percentage glacier area loss (Fig. 5). Glacier shrinkage in all glacier size classes was greatest in the Kuitun river basin, with its many small glaciers $\left(<1 \mathrm{~km}^{2}\right)$, followed by the Jinghe river basin $(15.4 \%)$ and the Sikeshu river basin (15.3\%). Both of the latter are in the outer ranges of the Tien Shan. The Bortala river basin, located in the interior, exhibited comparatively small reductions $(12.6 \%)$.

\section{DISCUSSION}

\subsection{Reasons for glacier change}

\subsubsection{Glacier retreat and climate}

Of all the factors contributing to glacier variation, climate change may be the most important (Liu and others, 2002; Wang and others, 2009). Glacier fluctuations on timescales longer than a century are controlled mainly by temperature, 

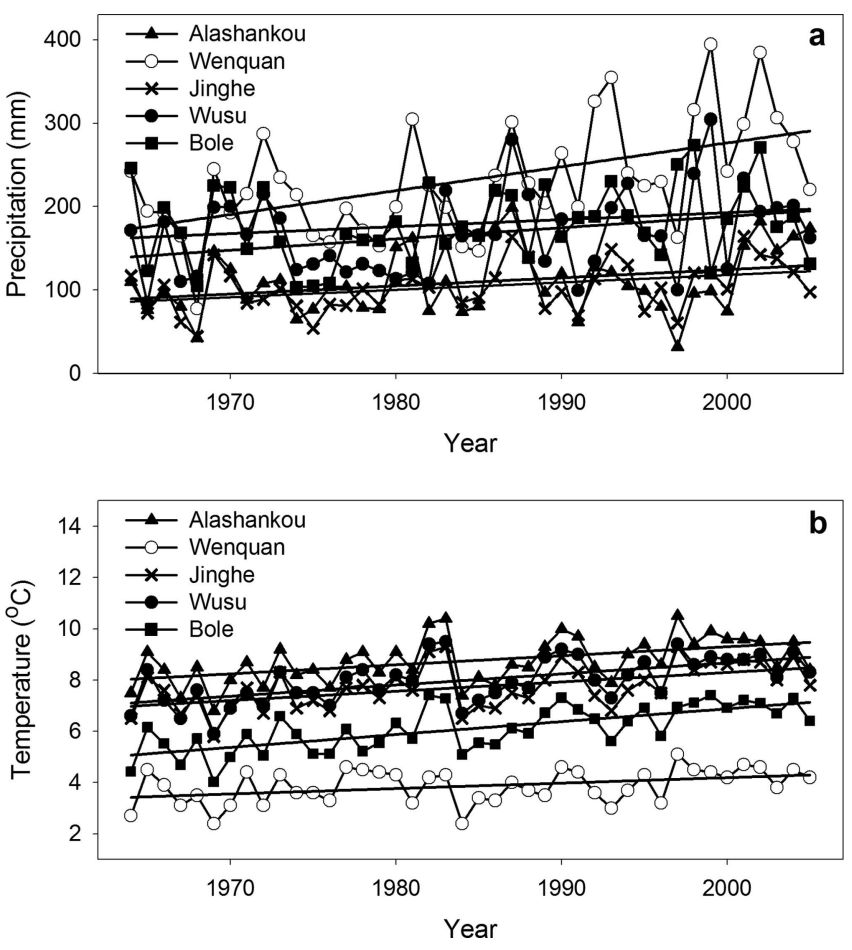

Fig. 6. (a) Annual average precipitation and (b) annual average temperature for 1959-2005 at the five meteorological stations in the study area.

not precipitation. Glacier fluctuations on timescales shorter than 10 years, or in a limited spatial scale, are determined by precipitation (Gao and others, 2000). Glacier changes in the study area were predominantly influenced by annual temperature and precipitation. Therefore, daily air temperature and precipitation data from five high-altitude meteorological stations in the Ebinur lake basin with a long period of observations were used (Table 2; Fig. 1a). All the data used were from 1959 to 2005.

Annual mean temperature and total precipitation over the 47 year period 1959-2005 were analyzed from the five closest stations in the study area (Fig. 6). The linear trend analysis of mean temperature indicated that the average rate of temperature increase was $0.31^{\circ} \mathrm{C}(10 \mathrm{a})^{-1}$. The periods 1959-90 and 1990-2005 were chosen because of a climate shift at the end of the 1980s in northwest China which resulted in a trend change (Shi and others, 2007). There is a warming trend of $0.25^{\circ} \mathrm{C}(10 \mathrm{a})^{-1}$ during the period 1959-90, which increases to $0.54^{\circ} \mathrm{C}(10 \mathrm{a})^{-1}$ from 1990 to 2005 . Thus, we have observed an increased rate of warming in recent

Table 2. Meteorological stations used in this study (locations are shown in Fig. 1a)

\begin{tabular}{lcccc}
$\begin{array}{l}\text { District station } \\
\text { No. }\end{array}$ & $\begin{array}{c}\text { Meteorological } \\
\text { station }\end{array}$ & Lat. (N) & Long. (E) & Altitude \\
& & & & ma.s.l. \\
\hline 51232 & Alashankou & $45^{\circ} 11^{\prime}$ & $82^{\circ} 35^{\prime}$ & 284.8 \\
51238 & Bole & $44^{\circ} 54^{\prime}$ & $82^{\circ} 04^{\prime}$ & 531.9 \\
51330 & Wenquan & $44^{\circ} 58^{\prime}$ & $81^{\circ} 01^{\prime}$ & 1354.6 \\
51334 & Jinghe & $44^{\circ} 37^{\prime}$ & $82^{\circ} 54^{\prime}$ & 320.1 \\
51346 & Wusu & $44^{\circ} 26^{\prime}$ & $84^{\circ} 40^{\prime}$ & 478.8
\end{tabular}

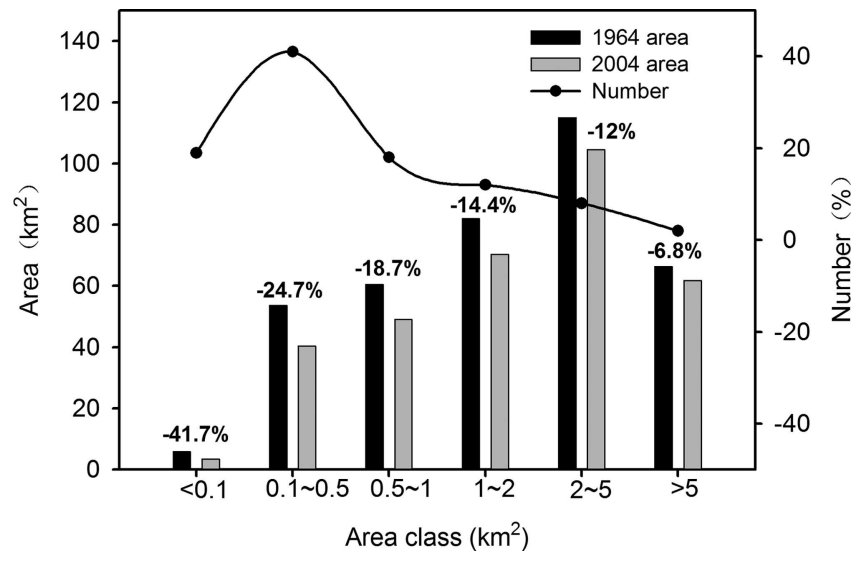

Fig. 7. Area, number, and area loss of glaciers by glacier size class for 1964-2004 in the Ebinur lake basin.

times. From 1959 to 2005, records at the five stations displayed a gradual increase in annual precipitation, at an average rate of $7.12 \mathrm{~mm}(10 \mathrm{a})^{-1}$. The rate of increase was $13.6 \mathrm{~mm}(10 \mathrm{a})^{-1}$ from 1959 to $1987,14.3 \mathrm{~mm}(10 \mathrm{a})^{-1}$ from 1980 to 1995 , and $123.3 \mathrm{~mm}(10 \mathrm{a})^{-1}$ from 1987 to 2005. Thus, annual precipitation has continually increased since 1980. Increasing temperature leads to: (1) increased energy available for ice- and snowmelt, (2) decreased snow accumulation and (3) lower albedo of the glacier surface (Ageta and Kadota, 1992; Fujita and Ageta, 2000). The precipitation increase has provided good conditions for glacier accumulation. However, the temperature increase has caused an increase in rain, rather than snow, in the highaltitude glacierized area, leading to reduced accumulation and accelerated ablation, especially in the summer (Chaulagai, 2003). Although the annual temperature generally increased between 1959 and 2005, slightly increasing annual precipitation leads to significant glacier melt, which appears to be the most significant factor for recent glacier shrinkage in the Ebinur lake basin.

\subsubsection{Glacier retreat and size}

During the period 1964-2004, the glaciers in the Ebinur lake basin shrunk by $14.7 \%$, from $366.32 \mathrm{~km}^{2}$ to $312.53 \mathrm{~km}^{2}$. This strong relative reduction tended to affect smaller glaciers the most (Fig. 7 ): $\sim 78 \%$ of these glaciers were $<1 \mathrm{~km}^{2}$ in area. Glaciers in different size classes $(<0.1$, $0.1-0.5,0.5-1,1-2,2-5$ and $>5 \mathrm{~km}^{2}$ ) experienced different area loss given different climate scenarios. With a short climate warming response time, small-glacier change was highly variable, which may be attributed to microclimate conditions or complicated topographic settings. Thus, a large number of small glaciers will affect the relative area change on a regional scale. The results also show a shift towards fewer and smaller glaciers over this period, due to net area loss. It is suggested that more glaciers will shrink and are likely to vanish in the near future.

\subsubsection{Glacier retreat and slope}

Glacier distribution was classified into 11 slope intervals $\left(<15^{\circ},>60^{\circ}\right.$ and $5^{\circ}$ intervals in between; Fig. 8). The six intervals at $<40^{\circ}$ slope have a combined area of $336.27 \mathrm{~km}^{2}$ and account for $91.8 \%$ of the total area and 318 glaciers (71.3\% of the total number). The other five intervals have a total area of $30.05 \mathrm{~km}^{2}$ and account for $8.2 \%$ of the total area and 128 glaciers $(28.7 \%)$. 


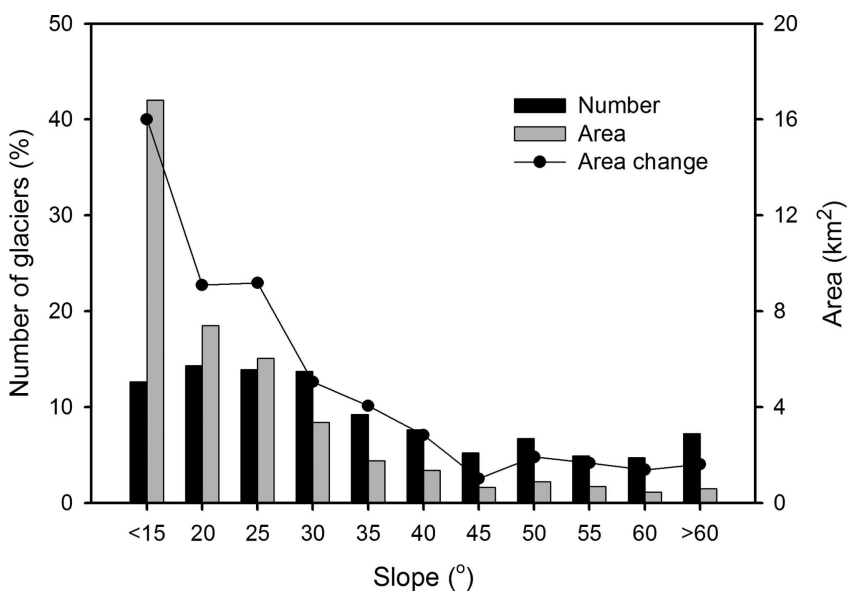

Fig. 8. Number, area and area loss of glaciers during 1964-2004 by slope in the Ebinur lake basin.

All slopes showed a reduction in glacier area from 1964 to 2004 (Fig. 8). The largest area change occurs for slopes of $<40^{\circ}$, with a combined area reduction of $46.11 \mathrm{~km}^{2}(85.0 \%$ of the total decrease). At slopes of $>40^{\circ}$ there is a total area reduction of $8.15 \mathrm{~km}^{2}(15.0 \%)$. Therefore, the lower the slope angle, the larger tends to be the area decrease, mainly as a result of glacier size.

\subsubsection{Glacier retreat and aspect}

Glacier distribution as a function of aspect was analyzed utilizing eight $45^{\circ}$ intervals (Fig. 9). In the 1960s, the proportion of the total number of glaciers was $>10 \%$ in each of four aspects (north, northeast, northwest and west), accounting for $76.3 \%$ of the total number of glaciers, while the other four aspects (south, southeast, southwest and east) accounted for $23.7 \%$ of the total number of glaciers. The total glacier area was $>10 \%$ in each of three aspects (north, northeast and northwest), accounting for $71.3 \%$ of total glacier area. The difference in glacier area and number distribution is predominantly influenced by local climate and topography effects.

The different aspects all showed glacier retreat between 1964 and 2004 (Fig. 9). The largest relative rates of change, shown in three aspects (south, southwest and west), were $26.5 \%, 21.1 \%$ and $16.8 \%$, respectively. The largest absolute rates of change were shown by the other five aspects (north, northeast, northwest, east and southeast), with a combined area reduction of $47.65 \mathrm{~km}^{2}$, accounting for $82.9 \%$ of the total reduction in glacier area. The south, southwest and west aspects included a smaller average glacier area. Thus, in addition to local climate and topography, the average area, the percentage of glacier area and the number of glaciers are all impact factors.

\subsection{Changes in ice volume}

The significant decrease in the areal extent of glaciers discussed above is accompanied by large volumetric ice losses. The relationship between ice volume and area can be defined as $V=c S^{\gamma}$, where $\gamma=1.36$ and 1.25 for glaciers and ice caps, respectively (Bahr and others, 1997; Liu and others, 2003). However, this formula is limited by the determination of the empirical constant $c$, and Bahr and others (2009) suggested a volume dependence only on relative area change: $\left(1+p_{v}\right)=\left(1+p_{\mathrm{s}}\right)^{\gamma}$, where $p_{\mathrm{v}}$ is the estimated change in volume and $p_{\mathrm{s}}$ is the change in area.

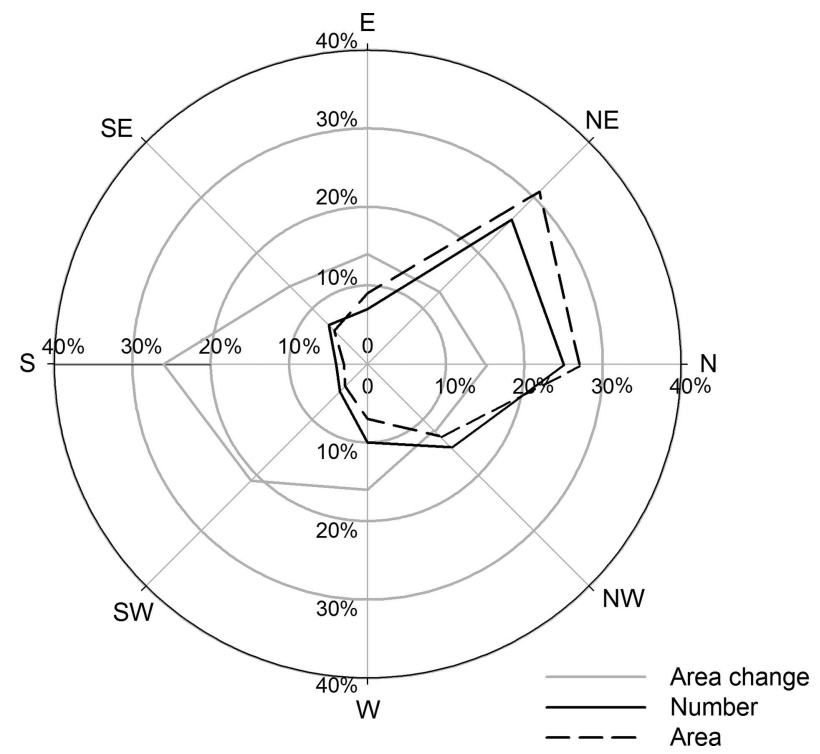

Fig. 9. Number, area and area loss during 1964-2004 by aspect in the Ebinur lake basin.

Based on the change in glacier area of the Ebinur lake basin $(14.7 \%)$, ice volume decrease is estimated to be $20.5 \%$ from 1964 to 2004 . That is, during the past $\sim 40$ years the ice volume of the basin has shrunk from $47.5 \mathrm{~km}^{3}$ (Liu and Ding, 1986) to $37.8 \mathrm{~km}^{3}$. Considering the southern and northern slopes separately, the estimated volume losses are $37.6 \%$ and $21.6 \%$, respectively. This ice loss, at a rate of $0.8 \% \mathrm{a}^{-1}$, is due to the small sizes of the glaciers $\left(<1 \mathrm{~km}^{2}\right)$ and is faster than in the eastern Xinjiang ( $\mathrm{Li}$ and others, $2011 b)$. The glacial meltwater in the Kuitun, Sikeshu, Jinghe and Bortala river basins accounts for 23.7\%, 29.6\%, 20.6\% and $21.4 \%$ respectively of the river runoff (Liu and Ding, 1986). High ice depletion rates are a warning signal for future local water supplies.

\subsection{Potential effect on regional water resources}

The Ebinur lake basin is seriously water-deficient. Glacier melt runoff in this region plays a significant role in the economic development of Xinjiang, and it is important to determine where glacier shrinkage will have most potential to affect lowland areas. Water supply for these rivers relies on input from glaciers, snow and precipitation. The total surface runoff in the Ebinur lake basin is $42.19 \times 10^{8} \mathrm{~m}^{3}$. In the basin, the rivers with annual runoff greater than $1 \times 10^{8} \mathrm{~m}^{3}$ are the Kuitun, Sikeshu, Jinghe, Daheyanzi and Bortala rivers. However, due to large-scale water conservancy construction since 1949, and especially since the 1980s, Kuitun river basin surface runoff has been exhausted and the Bortala and Jinghe rivers have become the main supply rivers of Ebinur lake. The measured data show that a significant increase in air temperature and precipitation has occurred in the Ebinur lake region since 1985 (Fig. 6). Alpine glaciers, especially those on southern slopes, have experienced strong retreat, and a marked warming trend has resulted in glacier wastage. Currently, small glaciers $\left(<1.0 \mathrm{~km}^{2}\right)$ are melting rapidly; the glacierized area within the Ebinur lake basin decreased by $22.9 \%$ (from $110.2 \mathrm{~km}^{2}$ to $85.0 \mathrm{~km}^{2}$ ) during $1964-2004$, which has added to the flow of downstream rivers. However, the area of small glaciers only accounts for $27.2 \%$ of the total area in 2004 . The larger glaciers $\left(>1.0 \mathrm{~km}^{2}\right)$ accounted for $23.3 \%$ in terms 

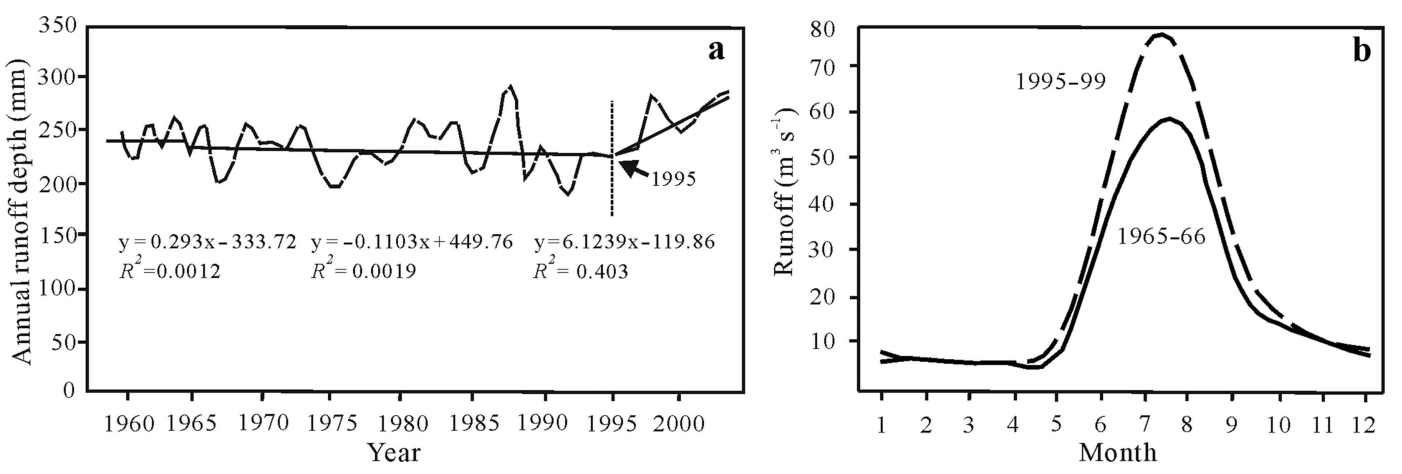

Fig. 10. Change curve of (a) annual runoff depth trend in the Ebinur lake basin and (b) runoff at Jiangjun Miao station.

of numbers, but $\sim 72.8 \%$ of the total area in 2004 . Thus, glaciers larger than $1 \mathrm{~km}^{2}$ are the main supplier of water resources. As glacier melting proceeds, larger glaciers reduce to smaller glaciers, thus weakening the regulatory effect of larger glaciers on river runoff.

Runoff in the Tarim river basin, which has a large number of glaciers distributed in its upstream reaches, has significantly increased since 1990 due to accelerated glacier melting (Gao and others, 2010). However, there are fewer glaciers in the Ebinur lake basin than in the Tarim basin, and previous studies have suggested a different reason for runoff variability in the region. Measured annual runoff was $236 \mathrm{~mm}$ over the 43 years 1959-2001 (Fig. 10a; data from Qiao and others, 2010). The minimum occurred in 1992 $(188.5 \mathrm{~mm})$, the maximum occurred in 1988 (294.8 $\mathrm{mm})$, interannual changes have increased and there is a clear increasing trend since 1995. In the Ebinur lake basin, runoff variation was observed to be closely related to precipitation and air temperature. Clearly, glaciers in the upper reaches of a river have an important role in stabilizing runoff. In general, alpine glaciers collect solid precipitation that melts to become meltwater to supply rivers in the summer or dry seasons, thereby keeping river runoff stable. For a river without a glacier supply, the coefficient of variation for runoff is variable.

The northern foot of the Tien Shan is a vital ribbon of economic development in the Xinjiang region (Tang and others, 2013). The people of the Ebinur lake basin region rely on glacier meltwater for domestic water, irrigation, industry and hydropower (Liu and others, 2002). As economic activities and population increase, the water shortage in the Ebinur lake basin and in the lowland cities limits economic development and domestic water use. In the Kuitun river basin, for which there are more systematic monitoring data, the river freeze factor (the percentage of rivers that freeze in the winter) is $10.3 \%$, the annual average runoff is $6.44 \times 10^{8} \mathrm{~m}^{3}$, and the volume of glacial meltwater is $1.510 \times 10^{8} \mathrm{~m}^{3}$, accounting for $23.7 \%$ of the river runoff (Liu and Ding, 1986; Gao and others, 2009). As shown in Figure 10b, annual runoff in the Kuitun river basin (data from Jiangjunmiao hydrometeorological station, $1392 \mathrm{ma.s.l.)}$ exhibits significant seasonal variation. The runoff was concentrated in June-September and closely related to high temperatures, snow and glacial meltwater. Runoff was significantly higher from 1995 to 1999 than from 1965 to 1966. If climate warming causes ice loss to continue at rates like those reported in the present study, downstream water sources will also deplete, endangering local economic development and people's safety.

\section{CONCLUSION AND FUTURE RESEARCH}

Glaciers in the Ebinur lake basin decreased significantly in area during the period 1964-2004: 446 glaciers investigated decreased in area by $14.7 \%\left(0.4 \% \mathrm{a}^{-1}\right)$, corresponding to a volume loss of $20.5 \%$. Glaciers smaller than $0.5 \mathrm{~km}^{2}$ experienced the strongest retreat, whereas glaciers larger than $2 \mathrm{~km}^{2}$ retreated less. The larger glaciers, however, may be the main contributors to river runoff in the future. Over the past $\sim 40$ years, glacier area has decreased by $15.4 \%$ in the Kuitun river basin, $15.3 \%$ in the Sikeshu river basin, $15.2 \%$ in the Jinghe river basin and $12.6 \%$ in the Boertala river basin, these being the subregions investigated within the Ebinur lake basin. Glacier shrinkage in the Ebinur lake basin mainly resulted from increasing temperatures. Regional differences in glacier area change are related to local climate conditions, the relative proportion of glaciers in different size classes and other factors. Glacial ablation in the Ebinur lake basin tends to be strong and water resources in this region are deteriorating. Glacier melt runoff in this region has played a significant role in the economic development of Xinjiang.

According to previous studies, alpine glaciers contribute an average of $23.7 \%$ of the annual flow of the Kuitun river (Liu and Ding, 1986; Gao and others, 2009). An understanding of the present state of glaciers is essential for the reasonable development and utilization of regional water resources, water cycle models and regional economic planning. Although glacial change over the past few decades has been investigated quantitatively here, the volumetric change was estimated based on an empirical formula. The effect of glacier change on water resources has been limited to qualitative analyses. More detailed research using reliable glacier field data is needed to confirm the calculations made here. Simulation and projection of future runoff trends are also needed to ascertain the relationship between changes in glacier properties and runoff variability.

\section{ACKNOWLEDGEMENTS}

This research was supported by the Science Fund for Creative Research Groups of the National Natural Science Foundation of China (41121001), the National Basic Research Program of China (Nos. 2010CB951003, 2013CBA01801), the State Key Laboratory of Cryospheric Sciences (SKLCS-ZZ-2012-01-01, SKLCS-ZZ-2012-01-09) and the National Natural Science Foundation of China (Nos. 41171057, 41101066, 41301069). 


\section{REFERENCES}

Ageta Y and Kadota T (1992) Predictions of changes of glacier mass balance in the Nepal Himalaya and Tibetan Plateau: a case study of air temperature increase for three glaciers. Ann. Glaciol., 16, 89-94

Aizen VB, Aizen EM, Melack JM and Dozier J (1997) Climatic and hydrological change in the Tien Shan, central Asia. J. Climate, 10(6), 1393-1404 (doi: 10.1175/1520-0442(1997)010<1393 $\mathrm{CAHCIT}>2.0 . \mathrm{CO} ; 2)$

Aizen VB, Kuzmichenok VA, Surazakov A and Aizen E (2006) Glacier changes in the central and northern Tien Shan during the last 140 years based on surface and remote-sensing data. Ann. Glaciol., 43, 202-213 (doi: 10.3189/172756406781812465)

Bahr DB, Meier MF and Peckham SD (1997) The physical basis of glacier volume-area scaling. J. Geophys. Res., 102(B9), 20355-20362 (doi: 10.1029/97JB01696)

Bahr DB, Pfeffer WT, Sassolas C and Meier MF (1998) Response time of glaciers as a function of size and mass balance. 1. Theory. J. Geophys. Res., 103(B5), 9777-9782 (doi: 10.1029/98JB00507)

Bahr DB, Dyurgerov M and Meier MF (2009) Sea-level rise from glaciers and ice caps: a lower bound. Geophys. Res. Lett., 36(3), L03501 (doi: 10.1029/2008GL036309)

Bolch T and Marchenko S (2009) Significance of glaciers, rockglaciers and ice-rich permafrost in the Northern Tien Shan as water towers under climate change conditions. In Braun LN, Hagg W, Severskiy IV and Young G eds. Selected papers from the Workshop on the Assessment of Snow, Glacier and Water Resources in Asia, 28-30 November 2006, Almaty, Kazakhstan. (IHP/HWRP-Berichte 8) UNESC-International Hydrological Programme and IHP/HWRP National Committee, Germany, Koblenz, 132-144

Chaulagai N (2003) Impact of climate changes on water resources of Nepal: a case study of Tsho Rolpa glacial lake. (MSc thesis, University of Flensburg)

Fujita K and Ageta $Y$ (2000) Effect of summer accumulation on glacier mass balance on the Tibetan Plateau revealed by massbalance model. J. Glaciol., 46(153), 244-252 (doi: 10.3189/ 172756500781832945)

Gao X, Tang M and Feng S (2000) Discussion on the relationship between glacial fluctuation and climate change. Plateau Meteorol., 19(1), 9-16 [in Chinese with English summary]

Gao W, Ma X, Zhang J and Fan Y (2009) Characteristics and tendencies of annual runoff variations in Kuitun River and its influential factors. J. Arid Land Res. Environ., 23(12), 139-144 [in Chinese with English summary]

Gao X, Ye B, Zhang S, Qiao C and Zhang X (2010) Glacier runoff variation and its influence on river runoff during 1961-2006 in the Tarim River Basin, China. Sci. China: Earth Sci., 53(6), 880-891

Haeberli W (2005) Mountain glaciers in global climate-related observing systems. In Huber UM, Bugmann HKM and Reasoner MA eds. Global change and mountain regions: an overview of current knowledge. (Advances in Global Change Research 23) Springer, Dordrecht, 169-175

Hagg W, Braun LN, Kuhn M and Nesgaard TI (2007) Modelling of hydrological response to climate change in glacierized Central Asian catchments. J. Hydrol., 332(1-2), 40-53 (doi: 10.1016/ j.jhydrol.2006.06.021)

Kehrwald NM and 8 others (2008) Mass loss on the Himalayan glaciers endangers water resources. Geophys. Res. Lett., 35(22), L22503 (doi: 10.1029/2008GL035556)

Khromova TE, Dyurgerov MB and Barry RG (2003) Late-twentieth century changes in glacier extent in the Ak-shirak Range, Central Asia, determined from historical data and ASTER imagery. Geophys. Res. Lett., 30(16), 1863 (doi: 10.1029/2003GL017233)

Kutuzov S and Shahgedanova M (2009) Glacier retreat and climatic variability in the eastern Terskey-Alatoo, inner Tien Shan between the middle of the 19th century and beginning of the 21st century. Global Planet. Change, 69(1-2), 59-70 (doi: 10.1016/j.gloplacha.2009.07.001)
Lemke P and 10 others (2007) Observations: changes in snow, ice and frozen ground. In Solomon $\mathrm{S}$ and 7 others eds. Climate change 2007: the physical science basis. Contribution of Working Group I to the Fourth Assessment Report of the Intergovernmental Panel on Climate Change. Cambridge University Press, Cambridge, 339-383

Li B, Chen Y, Shi X, Chen Z and Li W (2013) Temperature and precipitation changes in different environments in the arid region of northwest China. Theor. Appl. Climatol., 112(3-4), 589-596 (doi: 10.1007/s00704-012-0753-4)

Li K, Li H, Wang L and Gao W (2011a) On the relationship between local topography and small glacier change under climatic warming on Mt. Bogda, eastern Tian Shan, China. J. Earth Sci., 22(4), 515-527 (doi: 10.1007/s12583-011-0204-7)

Li K, Li Z, Gao W and Wang L (2011b) Recent glacial retreat and its effect on water resources in eastern Xinjiang. Chinese Sci. Bull., 56(33), 3596-3604 (doi: 10.1007/s11434-011-4720-8)

Li Y, Chu X and Jin H (2006) Study on changes of hydrological characteristics of Ebinur lake basin in Xinjiang. J. China Hydrol., 26(5), 68-71 [in Chinese]

Liu C and Ding L (1986) Distributive and active features of the glaciers in interior drainage area of Junggar Basin in northwest Tianshan mountains. In Lai Z, Cao Z and Liu C eds. Glacier inventory of China III. Tien Shan mountains (interior drainage area of Jung-gar Basin in northwest). Science Press, Beijing, 135-198 [in Chinese]

Liu C, Xie Z, Liu S, Chen J and Sen Y (2002) Glacial water resources and their change. In Kang E ed. Glacier-snow water resources and mountain runoff in the arid area of Northwest China. Science Press, Beijing [in Chinese]

Liu S, Sun W, Shen Y and Li G (2003) Glacier changes since the Little Ice Age maximum in the western Qilian Shan, northwest China, and consequences of glacier runoff for water supply. J. Glaciol., 49(164), 117-124 (doi: 10.3189/172756503781830926)

Ma M, Wang X, Veroustraete F and Dong L (2007) Change in area of Ebinur Lake during the 1998-2005 period. Int. J. Remote Sens., 28(24), 5523-5533 (doi: 10.1080/01431160601009698)

Narama C, Kääb A, Duishonakunov M and Abdrakhmatov K (2010) Spatial variability of recent glacier area changes in the Tien Shan Mountains, Central Asia, using Corona ( 1970), Landsat ( 2000), and ALOS ( 2007) satellite data. Global Planet. Change, 71(1-2), 42-54 (doi: 10.1016/j.gloplacha.2009.08.002)

Oerlemans J (2005) Extracting a climate signal from 169 glacier records. Science, 308(5722), 675-677 (doi: 10.1126/ science.1107046)

Pan BT and 7 others (2013) Glacier changes from 1966-2009 in the Gongga Mountains, on the south-eastern margin of the QinghaiTibetan Plateau and their climatic forcing. Cryosphere, 6(5), 1087-1101 (doi: 10.5194/tc-6-1087-2012)

Paul F, Kääb A, Maisch M, Kellenberger T and Haeberli W (2002) The new remote-sensing-derived Swiss glacier inventory: I. Methods. Ann. Glaciol., 34, 355-361 (doi: 10.3189/ 172756402781817941)

Paul F, Kääb A, Maisch M, Kellenberger T and Haeberli W (2004a) Rapid disintegration of Alpine glaciers observed with satellite data. Geophys. Res. Lett., 31(21), L21402 (doi: 10.1029/ 2004GL020816)

Paul F, Huggel C and Kääb A (2004b) Combining satellite multispectral image data and a digital elevation model for mapping debris-covered glaciers. Remote Sens. Environ., 89(4), 510-518 (doi: 10.1016/j.rse.2003.11.007)

Qiao M, Zhou S and Lu L (2010) Trends in runoff variations of the Ebinur lake basin during the last 48 years. J. Soil Water Conserv., 24(6), 236-239 [in Chinese]

Raup B and 11 others (2007a) Remote sensing and GIS technology in the Global Land Ice Measurements from Space (GLIMS) Project. Comput. Geosci., 33(1), 104-125 (doi: 10.1016/ j.cageo.2006.05.015)

Raup B, Racoviteanu A, Khalsa SJS, Helm C, Armstrong R and Arnaud Y (2007b) The GLIMS geospatial glacier database: a new 
tool for studying glacier change. Global Planet. Change, 56(1-2), 101-110 (doi: 10.1016/j.gloplacha.2006.07.018)

Shi $Y$ and 6 others (2007) Recent and future climate change in northwest China. Climatic Change, 80(3-4), 379-393 (doi: 10.1007/s10584-006-9121-7)

Solomina O, Barry R and Bodnya M (2004) The retreat of Tien Shan glaciers (Kyrgyzstan) since the Little Ice Age. Geogr. Ann. A, 86(2), 205-215 (doi: 10.1111/j.0435-3676.2004.00225.x)

Sorg A, Bolch T, Stoffel M, Solomina O and Beniston M (2012) Climate change impacts on glaciers and runoff in Tien Shan (Central Asia). Nature Climate Change, 2(10), 725-731 (doi: 10.1038/nclimate1592)

Surzakov AB, Aizen VB, Aizen EM and Nikitin SA (2007) Glacier changes in the Siberian Altai Mountains, Ob river basin, (1952-2006) estimated with high resolution imagery. Environ. Res. Lett., 2(4), 045017 (doi: 10.1088/1748-9326/ 2/4/045017)

Svoboda F and Paul F (2009) A new glacier inventory on southern Baffin Island, Canada, from ASTER data: I. Applied methods, challenges and solutions. Ann. Glaciol., 50(53), 11-21 (doi: 10.3189/172756410790595912)

Tang X, Xue L, Zhang Z and Lv X (2013) Effects of glacier melting on socioeconomic development in the Manas River basin, China. Natur. Hazards, 66(2), 533-544 (doi: 10.1007/s11069-0120499-4)
Wang L, Li Z and Wang F (2011a) Spatial distribution of the debris layer on glaciers of the Tuomuer Peak, western Tian Shan. J. Earth Sci., 22(4), 528-538 (doi: 10.1007/s12583-011-0205-6)

Wang P, Li Z and Gao W (2011b) Rapid shrinking of glaciers in the Middle Qilian Mountain region of Northwest China during the last $\sim 50$ years. J. Earth Sci., 22(4), 539-548 (doi: 10.1007/ s12583-011-0195-4)

Wang Y, Hou S and Liu Y (2009) Glacier changes in the Karlik Shan, eastern Tien Shan, during 1971/72-2001/02. Ann. Glaciol., 50(53), 39-45 (doi: 10.3189/172756410790595877)

Xiao C and 6 others (2012) High Asia cryospheric observation: a proposed network under Global Cryosphere Watch (GCW). Sci. Cold Arid Regions, 4(1), 1-12

Yao TD, Wang YQ, Liu SY, Pu JC, Shen YP and Lu AX (2004) Recent glacial retreat in High Asia in China and its impact on water resource in Northwest China. Sci. China D, 47(12), 1065-1075 (doi: 10.1360/03yd0256)

Ye B, Ding Y and Liu C (2001) Response of valley glaciers in various sizes and their runoff to climate change. J. Glaciol. Geocryol., 23(2), 103-110

Ye Q, Kang S, Chen F and Wang J (2006) Monitoring glacier variations on Geladandong mountain, central Tibetan Plateau, from 1969 to 2002 using remote-sensing and GIS technologies. J. Glaciol., 52(179), 537-545 (doi: 10.3189/ 172756506781828359) 